\title{
Aspidosperma species (Apocynaceae) as sources of antimalarials: from the in vitro antiplasmodial activity of extracts to pre-clinical toxicological studies for the development of efficient and safe antimalarial phytomedicines
}

\author{
Alaide Braga de Oliveira ${ }^{1,2^{*}}$, Renata Cristina de Paula ${ }^{2}$, Maria Fani Dolabela ${ }^{1}$, Fabiola Rocha ${ }^{3}$, Fabiana Gomes ${ }^{2}$, \\ Giovanny Garavito ${ }^{4}$, Geraldo Célio Brandão ${ }^{6}$, Fúlvio Mendes ${ }^{5}$, Ricardo Tabach ${ }^{7}$
}

From Challanges in malaria research: Core science and innovation

Oxford, UK. 22-24 September 2014

We report here our investigations on plants belonging to the botanical genus Aspidosperma (Apocynaceae) that are used to treat malaria and/or fevers in Brazil, aiming to prepare standardized alkaloid extracts for phytomedicines development. Ethanol and alkaloid extracts of A. parvifolium and A. subincanum barks were prepared and their in vitro antiplasmodial activity was evaluated against Plasmodium falciparum (W2 strain) by the pLDH method. Bioguided fractionation of the active alkaloid extracts was undertaken. A study on antiplasmodial activity versus alkaloids content variation from three $A$. subincanum specimens that were collected in different regions was carried on by HPLC-UV. Ethanol and alkaloid extracts from A. parvifolium and A. subincanum were evaluated in toxicological studies in male and female Swiss mice and male Wistar rats $(\mathrm{n}=10)$; a control group was included in the experiments. At the end of treatment, animals were sacrificed, hematology and serum biochemical analyses were performed. Fractionation of alkaloid extracts from A. parvifolium and A. subincanum guided by in vitro assays against $P$. falciparum (W2 strain) led to the isolation of the indole alkaloids uleine (Oliveira et al., 2010) and N-demethyluleine. HPLC-UV and LC-UV-MS/ESI analyses of the extracts disclosed uleine as the major constituent, its content reaching $70.7 \%$ in the alkaloid extract from A. subincanum (ASALB) which was more potent than

'Universidade Federal do Pará - UFPA, Belem, Pará, Brazil

Full list of author information is available at the end of the article uleine and $\mathrm{N}$-demethyluleine themselves in the in vitro assays, as can be inferred from the selectivity indexes in relation to HepG2 cells $\left(\mathrm{SI}=\mathrm{CC}_{50} / \mathrm{IC}_{50}\right)$ of ASALB (100), uleine (44) and N-demethyluleine (21). Moreover, a significative variation on the contents of these two alkaloids was observed for the same plant species when collected in different regions (Paula, 2014). Both ethanol and alkaloid extracts from $A$. parvifolium bark were relatively safe, producing minor changes in the parameters evaluated, especially in smaller doses, thus making feasible their future use in phase I clinical trials. On the other hand, high toxicity of both extracts from A. subincanum bark was observed in doses $>200 \mathrm{mg} / \mathrm{kg}$. The present results point to the necessity of rigorous investigation of traditional antimalarial plants including in vitro studies for identification of active natural products, standardization of extracts to be submitted to pre-clinical toxicological studies and controlled clinical trials. Our results disclose that efficient and safe phytomedicines might be developed from standardized crude or semi-purified extracts of Aspidosperma species containing the active chemical entities.

\footnotetext{
Authors' details

'Universidade Federal do Pará - UFPA, Belem, Pará, Brazil. ${ }^{2}$ Universidade Federal de Minas Gerais - UFMG, Belo Horizonte, Minas Gerais, Brazil. ${ }^{3}$ Universidade Federal de Juiz de Fora - UFJF, Juiz de Fora, Minas Gerais, Brazil. ${ }^{4}$ Universidad Nacional de Colombia - UNAL, Bogotá, Colombia. ${ }^{5}$ Universidade Federal do ABC - UFABC, São Paulo, São Paulo, Brazil. ${ }^{6}$ Universidade Federal de Ouro Preto - UFOP, Ouro Preto, Minas Gerais, Brazil.
} 
Published: 22 September 2014

doi:10.1186/1475-2875-13-S1-P18

Cite this article as: Braga de Oliveira et al:: Aspidosperma species

(Apocynaceae) as sources of antimalarials: from the in vitro

antiplasmodial activity of extracts to pre-clinical toxicological studies for

the development of efficient and safe antimalarial phytomedicines.

Malaria Journal 2014 13(Suppl 1):P18.

Submit your next manuscript to BioMed Central and take full advantage of:

- Convenient online submission

- Thorough peer review

- No space constraints or color figure charges

- Immediate publication on acceptance

- Inclusion in PubMed, CAS, Scopus and Google Scholar

- Research which is freely available for redistribution

Submit your manuscript at www.biomedcentral.com/submit
C Biomed Central 